\title{
Methodologies Gamified as Didactic Resources for Social Sciences
}

\author{
https://doi.org/10.3991/ijet.v14i23.10794 \\ Isabel María Gómez Trigueros \\ University of Alicante, Alicante, Spain \\ isabel.gomez@ua.es
}

\begin{abstract}
In this paper we analyze the perception of teachers in training about the inclusion of elements of the game in education and its potential contribution to the learning of Social Sciences. First of all, the object of the study is specified; then, an analysis is developed from a mixed methodology, using as a tool a Likert scale questionnaire. Finally, we extract the results that allow us to analyze students who, in the future, will be professors and inform about the value of this type of resources and didactic strategies for the improvement in the teaching and learning processes of Social Sciences content. as well as the acquisition of key competences and the perception of the technologies, by the participating students, teachers in training, students of the Master's Degree in Teaching. In addition, the study establishes the importance for the training of teachers of the use of innovative methodological proposals, based on new technologies.
\end{abstract}

Keywords-Social Sciences, ITC, gamification, teaching staff, methodology

\section{Introduction}

In the 21 st century, teaching and learning models are immersed in a process of innovation and adaptation to new demands. Educating has stopped being the simple transmission of curricular contents of each nation, community or social environment to become a firm tool that trains students in key knowledge and skills. In this sense, current teachers must be trained and know the digital resources emerged in recent decades as well as their correct inclusion in the classroom [1, 2]. In the same way, teacher training centers, universities and other educational institutions can not be left out of such changes and must adjust to the novel demands of their students and society.

Among the current teaching methodologies of the Social Sciences are the gamified experiences and with Information and Communication Technologies (ICT). The inclusion of elements of the game in education is known as gamification. At a general level, the implementation of this type of strategies in education [3] has shown, from the analysis of different works, an increase in motivation [4], the development of competences [5] as well as greater creativity in the students [6]. The enormous progression of this type of educational methodologies has given rise to multiple theoretical proposals $[7,8]$ and practical works $[9,10]$ in which the applicability of such re- 
sources is verified for teaching and learning (EA). It is necessary that the implementation of the gamification in the classroom is planned beforehand, taking into account the need to carry out a follow-up and accompaniment of the students, systematizing the educational process to achieve the intended objectives and to strengthen the significant learning [11].

It should be noted that the actions that include gamification in higher education, worldwide, are scarce [10]. Although published literature indicates the need to enhance learning that promotes student motivation, autonomy and the achievement of lifelong learning, efforts seem not to focus on the inclusion of new methodologies. This can be seen in the 2015 OECD studies as well as various authors $[12,13]$. However, there is a lack of studies that show the assessment of the adequacy of such interventions with this type of tools and classroom strategies for the acquisition of Social Science content. Therefore, this study aims to provide, in general terms, how certain innovative pedagogical methodologies are developed; determine the effect they have on the teaching and learning processes; how they influence the learning process of university students, the design and implementation of a gamified course in which principles of connectivity and collaborative work are applied. A mixed type research (quantitative and qualitative) has been carried out from a classroom intervention with the purpose of contributing and offering a detailed analysis of the perception, acquisition and understanding of Social Science knowledge by the students of Master of Teacher's degree, from gamified proposals and with ICT in the classroom.

\subsection{Conceptualization and didactics of gamification}

We cannot forget the fact that the application of games for formal education has been used since antiquity as evidenced by texts by ancient philosophers [14]. In 1910 it is recognized the use of some playful elements for education within the Boys Scout movement as: the badges of recognition of achievements, the resolution of activities and group cooperation among others [2]. In the 70s, Clark Abt introduced the concept of serious games in his publication "Serious Games" which refers to the category of games non-oriented exclusively at entertainment [6]. This British therapist proposed using traditional games to improve learning in educational institutions and, thus, combat existing school failure, arguing that the use of playful elements in training contexts, and the consequent transformation of the classroom, offers the improvement of motivation. Likewise, it is insisted that such strategies allow to link, through the playful simulations, the teaching contents with the real world [15]. To defend these arguments, Abt highlights the characteristics of the human being that tends to participate, very positively, in playful contexts and, in this way, it is suggested to take advantage of that potential to reuse it in educational contexts. Such considerations have served as a starting point for some studies and proposals on the use of the game (and video game) in educational environments [16-21].

In the 90s, and as a result of technological advances, new ways of using games in learning appeared. Such is the case of "Math Blaster" and "The incredible Machine", [22] with great acceptance among the younger audience and not exempt from criti- 
cism because of being "too difficult to link to the curriculum" [22, p.23), as it focused on the practice repetitive mathematical skills such as addition and subtraction.

As already has been noted, the incorporation of elements of the game to the education is called gamification. Although this term includes different definitions, in this work is considered as the application of concepts and dynamics in a playful way in order to stimulate and make more attractive the teaching-learning process, and in this way students acquire specific curricular contents $[5,19,23]$. The intentionality is to make knowledge more fun and motivating than it would be if presented through a traditional class [4]. The gamification includes the implementation of game mechanics that enhance:

- Student participation.

- The development of key skills such as technological literacy.

- A higher level of motivation towards the contents proposed [19, 24]. An improvement in the analytical capacity, multitasking and the use of their creativity and imagination [6] among others.

\subsection{Motivation and gamification}

In relation to motivation, it should be noted that it is one of the most acclaimed potentialities with respect to gamified methodology [25, 2]. Motivation can be defined as a dynamic process, continuously changing increasing and decreasing [26]. According to [27], the motivation is verified through the commitment that a person shows towards an activity and that determines the intensity of his effort and his persistence in the resolution of this task. There are various theories about motivation such as Maslow's Theory of the Pyramid or Herzberg's Theory of Hygienic Factors. In the first, proposed by Abraham Maslow in 1943, the five levels in which human needs are ordered, are defined?. The top of such a hierarchy is self-realization; the way to ascend in the scale is to adopt an active attitude and the key to progress lies in the motivation of each individual [28]. On the other hand, the theory of the psychologist Frederick Herzberg (1968) affirms that the level of performance before an activity varies according to the level of satisfaction in people. Thus, it is insisted that the responses of each individual to work are different when they feel good or bad. To provide motivation, this theory proposes the enrichment of tasks consisting of the substitution of simpler and elementary activities by more complex ones, which offer conditions of challenge and personal satisfaction [29]. Both affect the importance of task enrichment. To implement meaningful gamified experiences, it is necessary to pay attention to the considerations of cognitivism in relation to the types of motivation. Two types are differentiated [30]: on the one hand the intrinsic motivation, which arises from the individual and moves him to carry out an activity because he likes it, attracts him and without having any external incentive. Valderrama [31] indicates that the didactic proposals through the game allow to activate such motivation for the simple pleasure of playing, discarding the compulsory character that the activities in educational contexts show. On the other hand, extrinsic motivation arises when what the individual wants is what he receives in exchange for the activity carried out. This type of motiva- 
tion is the one that has traditionally been used in schools through rating of notes and grades given to students $[26 ; 21]$.

In addition to the considerations of cognitivism, a gamified system must take into account the principles of constructivism. In this sense, other of the educational possibilities offered by gamification is the progressive construction of learning by students when interacting with novel, rich and diverse environments [32]. To such progress joins the development of commitment and autonomy [33] by overcoming challenges [34] and the acquisition of skills and superior skills, of thinking and coordination [35].

In the same way, educational gamification is associated with its value in so-called immersive training experiences [20] considered as those training actions that have the purpose of deepening and acquiring a wider knowledge about the contents that are being worked on, through the fun caused by the game. Thus, gamification enhances learning by achieving a better educational performance of the educational contexts in which it is implemented [36], with greater dedication on the part of students [37]. In addition, this methodology enriches project-based learning since it actively involves students, promotes cooperative learning [38] and teamwork.

In conclusion, the purpose of the gamified playful didactic is none other than "to incite action, promote learning and solve problems" [19, p. 9]. Through such methodologies, "it is intended to influence the psychological and social behavior of the player" [39, p. 2]. Also, the implementation of certain elements of the games such as levels, points, badges and similar increase the time of the participants in the activity and their willingness to continue with it. In this sense, a curricular design based on the principles of gamification promotes the interest of students, preventing disinterest in the learning process [40].

\subsection{Elements of Gamified educational strategies}

The implementation of gamified strategies in the classroom requires, as it has already been pointed out, a systematization of the process so that said methodology achieves the intended objectives. In order to be able to use such playful strategies and achieve the expected learning, a series of elements are needed such as:

- Define the educational objectives that are to be achieved in the classroom in such a way that a coherent and effective gamified intervention can be designed.

- Indicate, in a concrete manner, what kind of behaviors and attitudes you want to develop with the classroom intervention as well as the skills to be achieved.

- Identify the characteristics of the group in which the strategy is implemented in such a way that the activities are as close as possible to their interests, capacities, key competences, etc.

- Delimit the rhythms and types of exercises, defining the gamification system such as: the order of the game, the rules to be followed, the rhythm of student participation, detailing the mechanics of the game as well as the levels of challenge, badges, etc.

- Indicate what kind of entertainment and fun dynamics make up the gamified proposal. 
- Know and point out the tools and resources necessary to carry out the development of the strategy in the classroom [41].

In this context, this study aims, on the one hand, to evaluate the advantages and limitations of game techniques and gamification processes as methodological strategies in teacher training. On the other hand, it particularly seeks to analyze the perceptions of the students of Master of Teacher's degree on the active methodologies based on the game, and their potential as a tool for the achievement of curricular contents of Social Sciences.

\section{Methodological Design}

\subsection{Participant sample}

The target population of the study has been selected in a non-probabilistic, directed and intentional manner [42, 43], consists of 118 participants, teachers in training, of the Master's Degree in Secondary Education Teaching.

Table 1. Crossed table of descriptive values. Age and sex range

\begin{tabular}{|l|c|c|c|}
\multicolumn{1}{c|}{ Age range } & \multirow{2}{*}{ Secondary Master } & \multicolumn{2}{c|}{ Sex } \\
\cline { 3 - 4 } & & Woman & Man \\
\hline 22 years & 62 & 42 & 20 \\
\hline Between 23 and 26 years old & 40 & 25 & 15 \\
\hline Between 27 and 30 years & 12 & 5 & 7 \\
\hline More than 30 years & 4 & 0 & 4 \\
\hline TOTAL & 118 & 72 & 46 \\
\hline
\end{tabular}

The sample is considered significant with respect to the total of the existing population [44] and consists of 72 women (61\%) and 46 men (39\%). The age range is between 22 and over 30 years (Table 1), with an average age of 22.5 years (SD = 3.75 , range 22 to 33 years).

\subsection{Procedure}

This research collects descriptive information, based on a quantitative model of work [45], and the implementation of an online questionnaire in learning contexts of the Faculty of Education of the University of Alicante (Spain). This is a nonexperimental research design of an exploratory type, based on the use of the questionnaire as an information collection tool $[46,47]$. The research has been carried out during two academic years. The procedure has been, first of all, an exhaustive theoretical review on the teaching competences of the teachers in training; in a concrete way, attention has been paid to the digital teaching competence. Secondly, the design of the study instrument consisting of a Likert scale questionnaire was carried out (Table 2). In third place, it was validated by expert teachers from the Spanish universities of Burgos, Illes Balears and Murcia as well as researchers from the Faculty of Education 
of the University of Alicante. Fourth, the questionnaire was distributed through the free Google Form application, validated among the participating sample, with a previous supply of information on the use of the results and the confidentiality of their responses. Finally, the data obtained were analyzed and proposals were elaborated for the work of gramified strategies with ICT to improve and enrich the teacher training from the area of knowledge of Social Sciences Didactics.

\subsection{Instrument}

The measurement of the variables studied was carried out using the questionnaire proposed from a study of the same type implemented successfully and reused in subsequent studies [48], adapted to the research objectives and validated by experts from public universities already indicated. It is an instrument composed of 14 items (Table 2) organized into three blocks of content: the first, related to the sociodemographic characteristics of the sample (items 1-2); the second, related to the knowledge about the digital competence of the sample and about the new learning strategies (items 38 ); and the third, referred to the students' perception of the didactic possibilities offered by the gamified proposals and with ICT in the teaching and learning of the Social Sciences (items 9-14). The totality of the items respond to a Likert scale of 5 points that range from the value 1 strongly disagree to the value 5 totally agree.

Table 2. Questionnaire, instrument of the research

\begin{tabular}{|c|l|}
\hline Item & \multicolumn{1}{|c|}{ Descriptor of the statement analyzed } \\
\hline 1 & Sex \\
\hline 2 & Age \\
\hline 3 & I know what digital competence is. \\
\hline 4 & I know the concept of gamification. \\
\hline 5 & $\begin{array}{l}\text { I know different learning strategies with ICTs such as: MOOCs, gamification, Facebook and how to } \\
\text { use them. }\end{array}$ \\
\hline 6 & I believe that my digital competence is adequate for my future teaching job. \\
\hline 7 & ICT resources will be used for the teaching and learning of Social Sciences. \\
\hline 8 & $\begin{array}{l}\text { My digital competence allows me to incorporate new teaching strategies in the classroom of Social } \\
\text { Sciences such as gamification. }\end{array}$ \\
\hline 9 & I believe that gamification and ICTs help me in my training as a future or future teacher. \\
\hline 10 & Gamification is a useful strategy for the teaching and learning of Social Sciences. \\
\hline 11 & I believe that ICT help teachers as resources for the teaching and learning of Social Sciences. \\
\hline 12 & ICT and gamification can be important resources for the training of Social Sciences teachers. \\
\hline 13 & $\begin{array}{l}\text { The gamified didactic proposals allow a correct acquisition of knowledge in Social Sciences and an } \\
\text { adequate formation as future or future teacher. }\end{array}$ \\
\hline 14 & $\begin{array}{l}\text { The inclusion of ICT in the teaching-learning of Social Sciences allows the realization of didactic } \\
\text { proposals that help to achieve content, procedures, attitudes and key competences. }\end{array}$ \\
\hline
\end{tabular}

\subsection{Method of analyzing the results}

To corroborate the internal consistency and reliability of the questionnaire, psychometric tests have been carried out with the intention of knowing the reliability of 
the scale of measurement, concretely a reliability of $\alpha=.962$ has been found in the Cronbach's Alpha test, confirming a high internal and adequate consistency of the instrument for the proposed study $[49,50]$.

Likewise, to determine the validity of the internal structure of the instrument, a factorial analysis of the main components was carried out, in order to identify the latent factors that underlie the manifest variables, as well as the patterns of relations between latent and manifest variables. To do this, the KMO and Bartlett test has been used (Table 3). From the data obtained it can be concluded that the exploratory factor analysis is feasible, since the p-value (sig.) is $<0.05$ and that the correlation between all variables is high (the value obtained by the KMO test is 0.885 ).

Table 3. Test of KMO and Bartlett

\begin{tabular}{|l|l|c|}
\hline \multicolumn{2}{|c|}{ Kaiser-Meyer-Olkin measure of sampling adequacy } & $\mathbf{. 8 8 5}$ \\
\hline \multirow{3}{*}{ Bartlett's sphericity test } & Approx. Chi squared & 1025.675 \\
\cline { 2 - 3 } & gl & 145 \\
\cline { 2 - 3 } & S.I.G. & .000 \\
\hline
\end{tabular}

\section{$3 \quad$ Results}

\subsection{Analysis of descriptive data}

The descriptive statistics results (means and standard deviation) of each of the items are presented (Table 4). Of them, it is extracted that the perception of the students in relation to the strategies of gamification and the use of the TIC as resources for their own formation and their future teaching work is positive, observable in the items 9, 12 and $13(\mathrm{M} \geq 4.00$; DT $\leq 0.773)$, highlighting the importance that students give to this type of course for their training as future teachers. Likewise, it is observed that the sample identifies the concepts "digital competence" and "gamification" (item 3: $\mathrm{M}=4.94$, $\mathrm{DT}=0.699$, item $4: \mathrm{M}=4.53$, DT $=0.681$ and item $6: \mathrm{M}=4.67$; $\mathrm{DT}=$ 0.773 ).

As the results show, the sample recognizes its knowledge of strategies with technologies (item 5: $\mathrm{M}=4.87, \mathrm{DT}=0.861$ ). In the same way, they consider that they know how to use ICT resources to teach and learn Social Sciences (item 7: $M=4.42$, $\mathrm{DT}=0.815)$ and that they are able to incorporate new teaching and learning strategies such as gamification (item $8: \mathrm{M}=4.01 ; \mathrm{DT}=0.793$ ).

Regarding the perception on the utility of gamification (item 10: $\mathrm{M}=4.21$, DT $=$ 0.688 ) and its suitability for the correct acquisition of knowledge of Social Sciences (item 13: $\mathrm{M}=4.04$, DT $=0.773$ ), a positive consideration of ICT as a resource for classroom is noted (item 11: $\mathrm{M}=4.03, \mathrm{DM}=0.671$ ).

In relation to the training received in innovative technologies and strategies, students consider that they have been correctly trained to implement gamified educational interventions with ICT as shown by the values of items 13 and $14(\mathrm{M} \geq 4.00$; $\mathrm{DT} \leq 0.773$ ), indicative of a majority response of the participants equivalent to Agree. 
Thus, the participants consider that they have adequate training in technological resources to adequately implement such knowledge in their future teaching work, in the Social Sciences classroom.

Table 4. Descriptive results $(\mathrm{M}=$ mean, $\mathrm{DT}=$ standard deviation $)$

\begin{tabular}{|l|l|c|c|}
\hline Item & \multicolumn{1}{|c|}{ M } & DT \\
\hline 3 & I know what digital competence is. & 4.94 & 0.699 \\
\hline 4 & I know the concept of gamification. & 4.53 & 0.681 \\
\hline 5 & $\begin{array}{l}\text { I know different learning strategies with ICTs such as: MOOCs, gamification, } \\
\text { Facebook and how to use them. }\end{array}$ & 4.87 & 0.861 \\
\hline 6 & I believe that my digital competence is adequate for my future teaching job. & 4.67 & 0.773 \\
\hline 7 & ICT resources will be used for the teaching and learning of Social Sciences. & 4.42 & 0.815 \\
\hline 8 & $\begin{array}{l}\text { My digital competence allows me to incorporate new teaching strategies in the } \\
\text { classroom of Social Sciences such as gamification. }\end{array}$ & 4.01 & 0.793 \\
\hline 9 & $\begin{array}{l}\text { I believe that gamification and ICTs help me in my training as a future or future } \\
\text { teacher. }\end{array}$ & 4.02 & 0.667 \\
\hline 10 & Gamification is a useful strategy for the teaching and learning of Social Sciences. & 4.21 & 0.688 \\
\hline 11 & $\begin{array}{l}\text { I believe that ICT help teachers as resources for the teaching and learning of } \\
\text { Social Sciences. }\end{array}$ & 4.03 & 0.671 \\
\hline 12 & $\begin{array}{l}\text { The gamificacion is a strategy for the formation of the profesorado of Social } \\
\text { Sciences. }\end{array}$ & 4.00 & 0.721 \\
\hline 13 & $\begin{array}{l}\text { The gamified didactic proposals allow a correct acquisition of knowledge in } \\
\text { Social Sciences and an adequate formation as future or future teacher. }\end{array}$ & 4.04 & 0.773 \\
\hline 14 & $\begin{array}{l}\text { The implementation of gamification in the teaching-learning of Social Sciences } \\
\text { allows the realization of didactic proposals that help to achieve content, proce- } \\
\text { dures, attitudes and key competences. }\end{array}$ & 4.09 & 0.704 \\
\hline
\end{tabular}

\subsection{Correlation between the variables analyzed}

To know the relationship between the perceptions that the students have regarding their training in the use of play strategies, gamified and with technologies, Pearson's linear correlation analysis has been carried out (Table 5).

Table 5. Pearson's bivariate correlations

\begin{tabular}{|l|l|l|l|l|l|l|l|l|l|l|l|l|}
\hline Item & \multicolumn{1}{|c|}{$\mathbf{3}$} & \multicolumn{1}{|c|}{$\mathbf{4}$} & \multicolumn{1}{|c|}{$\mathbf{5}$} & $\mathbf{6}$ & $\mathbf{7}$ & $\mathbf{8}$ & $\mathbf{9}$ & $\mathbf{1 0}$ & $\mathbf{1 1}$ & $\mathbf{1 2}$ & $\mathbf{1 3}$ & $\mathbf{1 4}$ \\
\hline 3 & 1 & & & & & & & & & & & \\
\hline 4 & $.781 * *$ & 1 & & & & & & & & & & \\
\hline 5 & $.698 * *$ & $.867 * *$ & 1 & & & & & & & & & \\
\hline 6 & $.877 * *$ & $.698 * *$ & $.557 * *$ & 1 & & & & & & & & \\
\hline 7 & $.836 * *$ & $.570 * *$ & .448 & $.818^{*}$ & 1 & & & & & & & \\
\hline 8 & $.800 * *$ & $.511 *$ & $.462 *$ & $.854 * *$ & $.823 * *$ & 1 & & & & & & \\
\hline 9 & $.668 * *$ & $.554 * *$ & $.775 * *$ & $.637 * *$ & $.473 * *$ & $.875 * *$ & 1 & & & & & \\
\hline 10 & $.413 *$ & .422 & .827 & .372 & $.450 * *$ & $.870 * *$ & $.869 *$ & 1 & & & & \\
\hline 11 & .871 & .346 & .401 & $.755 *$ & .824 & $.885 * *$ & .354 & .323 & 1 & & & \\
\hline 12 & .250 & .796 & .816 & $.374 *$ & .311 & $.430 * *$ & .842 & .883 & .369 & 1 & & \\
\hline 13 & .226 & $.854 * *$ & $.835 * *$ & $.283 * *$ & $.231 * *$ & $.374 * *$ & $.769 * *$ & $.760 * *$ & $.339 * *$ & $.736 * *$ & 1 & \\
\hline 14 & .416 & .300 & $.797 *$ & $.249 * *$ & $.274 *$ & $.805 * *$ & $.897 * *$ & $.785 *$ & .735 & $.752 * *$ & $.706 * *$ & 1 \\
\hline
\end{tabular}

* The correlation is significant at the 0.05 level (bilateral).

** The correlation is significant at the 0.01 level (bilateral). 
In the results obtained it is observed that there is a high correlation between the knowledge of the concept "digital competence" (items 3,6 and 8) and their perception about the importance of the use and knowledge of ICT for teacher training (item 7 and 11 ), with a value $r \geq 0.800 ; p=0.00$ in all observed correlations). Likewise, a high correlation was found between items 4, 5, 9 and 10 and the application of the novel gamification strategy for the acquisition of knowledge of Social Sciences (items 12, 13 and 14) that yields $r \geq 0.770 ; p=0.00$ ).

Likewise, there is a high positive relationship between the consideration of ICT as resources for teacher training (items 9 and 11), its appreciation as a lever for the promotion and development of new tools in the Social Sciences classroom and its evaluation as mechanisms to promote key competencies (item $14, r \geq 0.735, p=0.00$ ). In this line, an important correlation between the inclusion of technologies and new gamified strategies and the perception about the usefulness of these didactic resources for Social Sciences is confirmed (items $10,12,13$ and $14, r \geq 0.735 ; p=0.00$ ).

Finally, the perception of the sample has been analyzed in relation to its training in technological content and digital competence, related to the future teaching work in the specific area of Social Sciences. In such interrelations, a positive correlation has been found (Table 5).

\section{Discussion and Conclusion}

The teacher's training of the 21st century, in the context of the Information and Communication Society, involves the implementation of educational strategies that include technologies. Thus, new teaching generations must achieve, in their training, a correct level of digital competence [51] defined as the provision to students of those skills that allow access to the contents of the SIC and critically discern its didactic use [2]. One of the main tasks of higher education centers and universities is therefore to provide digital teaching skills. The recognition of the use of technologies as one of the competences of today's teacher is included in the guidelines of the EHEA [52, 2]. For this reason, it is essential to know what the knowledge acquired by the students is and what perception they have of their training in digital teaching competence throughout their studies, in order to improve the study plans and discern the deficiencies in their training for a correct professional development.

In the same way, it is not enough to have a correct qualification in digital competences but it is also necessary to know classroom strategies that allow their adequate inclusion. Among them, the gamified methodology that, in addition to achieving the full incorporation of ICT in their processes, achieves greater student motivation [25, $2]$; activates the desire to learn (intrinsic motivation), revaluing tasks $[53,21]$ and increases the dedication of students in the activity and their willingness to continue with it as stated in this study. Thus, starting from the classroom intervention carried out and being aware of the difficulty involved in the evaluation of perceptions, in view of the results obtained, it is noted that Secondary Master students value highly innovative educational strategies such as gamification. Likewise, they consider that the inclusion of such resources in the Secondary Education classroom improves the 
teaching processes and the achievement of History learning, increasing their motivation, a conclusion that coincides with that of other similar studies [54, 55].

Also, the acknowledgment of the use of technologies as one of the key competences of today is confirmed [52, 2]. For this reason, it is essential to know what perception they have about their training in digital competence in the formative context of the Master of Secondary. In the same way, it is essential to address the implementation of ICT and gamified strategies from a didactic dimension [2].

In view of the results, the acceptance of the technologies is confirmed as positively valued tools for the learning of the Social Sciences by the participating students who, in the same way, recognize the enormous possibilities of the ICT for their training as future teachers of the 21 st century, granting it a character of indispensable tools for its inclusion in the current ICS. These assessments link with the reflections of similar works $[7,52,2]$. It should be noted that the attitude of students in relation to their digital competence is very positive. In this sense, the total sample shows a high qualification in the use of ICT.

These results are consistent with those obtained in other similar recent studies [56, 2], which shows the absence of difficulties for the manipulative use of the technologies of the teachers in training.

In relation to knowledge about the concept of gamification, it is found that the perception of the participants is positive and they recognize the educational value of said classroom strategy. In line with these values, students attribute great relevance to ICT in terms of its functionality as a resource to achieve the learning of Social Science content. This data coincides with other research that deals with this same topic [57, 58], and where it is clear that teachers in training consider it necessary to train in digital skills in order to carry out a correct inclusion of technological tools in their work. It should be noted that differential results have not been obtained according to the gender of the participants, giving the same importance to digital training in both genders.

In the analysis of the correlations between the variables, it is confirmed, in consonance with the contributions of Roig et al. [52] that the students know, have used the technologies and recognize the formative value for the teaching function of such didactic resources.

As reflected in international studies on the importance of ICT for lifelong learning of citizens [59-61], students recognize that gamified classroom interventions and technologies help to promote better training for future teachers, allowing access to information and resources available on the network and promoting significant learning in Social Sciences [62].

In the same way, a positive perception of the development of digital competence is identified through the implementation of novel methodologies (MOOCs and the use of gamified activities), promoting the creation of more motivating and creative classroom proposals in the area of Social Sciences.

All these values and analysis allow us to conclude affirming that the perception of the students, future teachers, about their own training in digital competences is adequate for their work as teachers. In the same way, a very positive assessment is found in relation to the strengths of the gamified strategies as resources for the Social Sci- 
ences classroom. In this sense, and although important actions are being carried out, in the Universities, from the educational administrations, there is still a lot of work to be done so that an optimum formative adaptation of the professionals of education can be verified to the demands of the ICS .

In reference to the limitations of this research, it should be noted that this is a study limited institutionally to the University of Alicante, so it should not be extended to the entire teaching community in the Spanish territory as well as to Latin America to corroborate or refute the evaluations that are presented here. In addition, the sampling has been for convenience and not probabilistic with the consequent limitations that this entails when it comes to reaching general conclusions. Likewise, it would be interesting to deepen in how these perceptions materialize in the teaching practice of the teaching staff participating in the research. Also, it would be interesting to extend this research to other areas such as mathematics, languages, etc. and, in this way, to be able to draw more general conclusions about innovation in the Master's classroom.

\section{Acknowledgement}

This research has been carried out under the umbrella of the Research Group of the University of Alicante (Spain) of Teacher training from an interdisciplinary perspective with ICT and TAC: challenges before the 21st century (UA 4351REDESICE18), directed by Dr. Isabel María Gómez Trigueros.

\section{References}

[1] Marín, V., López, M. \& Maldonado, G. Can Gamification Be Introduced Within Primary Classes?. Digital Education Review, 2015, 27, pp. 55-68. [Accessed 23/02/2019] http://gr eav.ub.edu/der

[2] Ortega, D. \& Gómez, I.M. Las WebQuests y los MOOCs en la enseñanza de las Ciencias Sociales y la formación del profesorado de Educación Primaria. Revista Electrónica Interuniversitariade Formación del Profesorado, 2017, 20(2), pp. 205-220. https://doi.org/10.60 $\underline{18 / \text { reifop/20.2.258551 }}$

[3] Dicheva, D., Dichev, Ch., Agre G. \& Angelova, G. Gamification in Education: A systematic Mapping Study. Journal of Educational Techology \& Spciety, 2015, 18(3), pp. 75-88.

[4] Oliva, HA. La gamificación como estrategia metodológica en el contexto educativo universitario. Realidad y Reflexión, 2017, 44(0), pp. 29-47. https://doi.org/10.5377/ryr.v44i0. $\underline{3563}$

[5] Burke, B. Gamification 2020: what is the future of gamification?, Standford: Gartnet, 2012.

[6] Gamson, W.A. SIMSOC: Simulated Society, Participant's Manual: Fifth Edition. New York, NY: The Free Press, 2000.

[7] Gómez-Trigueros, I.M. Análisis del paisaje físico y humano de la provincia de Alicante: Google Earth como herramienta docente en las clases de Geografía. GeoGraphos. Revista Digital para Estudiantes de Geografía y Ciencias Sociales, 2010, 1(1), pp. 1-26 [Accessed: 1/04/2019] http://web.ua.es/revista-geographos-giecryal https://doi.org/10.14198/geogra20 $\underline{10.1 .01}$ 
[8] Grandío-Pérez, M.M. El transmedia en la enseñanza universitaria. Análisis de las asignaturas de educación mediática en España (2012-2013). Palabra Clave, 2016, 19(1), pp. 85104. [Accessed: 23/03/2019] https://digitum.um.es/xmlui/bitstream/10201/47970/1/Trans media\%20en\%201a\%20Universidad.pdf https://doi.org/10.5294/pacla.2016.19.1.4

[9] Evaristo, I., Vega, V. \& Navarro, R. Uso de un videojuego educativo como herramienta para aprender historia del Perú. RIED. Revista Iberoamericana de Educación a Distancia, 2016, 19(2), pp.35-52. Recuperado de https://doi.org/10.5944/ried.19.2.15569

[10] Gómez-Trigueros, I.M. Gamificación y tecnologías como recursos y estrategias innovadores para la enseñanza y aprendizaje de la Historia. Educação \& Formação. 2018, 3(8), pp. 3-16. https://doi.org/10.25053/redufor.v3i8.267

[11] Bandura, A. Self-efficacy. The Exercise of Control, New York, NY: Worth Publishers, 1997.

[12] Gómez-Trigueros, I. M., Ruiz Bañuls, M., Ortega Sánchez, D., García-Valero, B. E., JuanPenalva, J., Segrelles, J. A., \& Formosinho, M. D. Propuestas transmedia y gamificación aplicadas al EEES: Nuevas metodologías activas para implementar las competencias en Ciencias Sociales y en Literatura. En: R. Roig-Vila (Coord.), Memorias del Programa de Redes-I3CE de calidad, innovación e investigación en docencia universitaria. Convocatoria 2016-17 (pp. 2433-2437). Alicante: Universidad de Alicante, Instituto de Ciencias de la Educación (ICE), 2017. https://doi.org/10.18004/mem.iics/1812-9528/2016.014(03)07-013

[13] Trujillo, F. Del juego a la gamificación. Mitos y leyendas de las TIC. Aula de innovación educativa, 2017, 267, pp. 38-40.

[14] Gómez Trigueros, I.M. \& Ruiz Bañuls, M. Análisis de metodologías activas con ABP, Transmedia y Gamificación para implementar las competencias en Ciencias Sociales y en Literatura. En R. Roig-Vila (Ed.). Investigación en docencia universitaria. Diseñando el futuro a partir de la innovación educative (pp. 245-254). Barcelona: Octaedro, 2017. https:// doi.org/10.4995/redu.2017.7405

[15] Abt, C. Serious Games, New York: University Press of America, 1987.

[16] Gros, B. Videojuegos y aprendizaje. Barcelona: Grao, 2008.

[17] Álvarez, J. \& Djaouti, D. Introduction au serious games, Paris, L $>$ P: Questions théoriques, 2010.

[18] Lacasa, P. Los videojuegos. Aprender en mundos reales y virtuales. Madrid: Morata, 2011.

[19] Kapp, K. Games, Gamification, and the quest for learner engagement. Training and Development, 2012, 66(6), pp. 64-68.

[20] Castellón, L. \& Jaramillo, O. Educación y videojuegos: hacia un aprendizaje inmersito. Homo Videoludens, 2012, 2, pp. 264-281.

[21] Palazón, J. Motivación del alumnado de educación secundaria a través del uso de insignias digitales. Opción, 2015, 31, pp. 1059-1079.

[22] Jara-Roa, D.I., Ramírez, M.S. \& Cabezas, M. Tecnologías y pedagogías emergentes instrumentadas en un Mooc en la Universidad Técnica Particular de Loja (UTPL). Riobamba, Ecuador: Edutec, 2015. https://doi.org/10.4185/rlcs-2012-966

[23] Zichermann, G., \& Linder, J. The gamification Revolution: how leaders leverage game mechanics to crush the competition. EUA: Mc Graw Hill Education, 2013.

[24] Kapp, K., Latham, W. \& Ford-Latham, H. Integrated learning for ERP success: a learning requirements planning approach. Florida: CRC Press, 2016. https://doi.org/10.1201/9781 $\underline{420025545}$

[25] Mikel, J. Gamificación: hagamos que aprender sea divertido (tesis de maestría). Pamplona, Navarra, España: Universidad Pública de Navarra, 2016.

[26] Soriano, M. La motivación, pilar básico de todo tipo de esfuerzo. Proyecto Social, 20019, pp. 163-184. 
[27] Garris, R., Ahlers, R. \& Driskell, J. Games, motivation, and learning: a research and practice model. Simulation \& Gaming, 2002, 33 (4), pp. 441-467. https://doi.org/10.1177/104 $\underline{6878102238607}$

[28] Reid-Cunningham, A.R. Maslow's Theory of Motivation and Hierarchy of Human Needs: A Critical Analysis, Berkeley. PhD Qualifying Examination School of Social Welfare University of California, 2008.

[29] Manso, J.F. El legado de Frederick Irving Herzberg”, Revista Universidad EAFIT, 2002, 128, pp. $79-86$.

[30] Woolfolk, A. Psicología Educativa. México: Prentice Hall, 2006.

[31] Valderrama, B. Los secretos de la gamificación: 10 motivos para jugar. Capital Humano, 2015, 295, pp. 73-78.

[32] Zubiría, H.D. El Constructivismo en los procesos de enseñanza-aprendizaje en el siglo XXI. Barcelona: Plaza y Valdés, 2004.

[33] Sailer, M., Hense, J., Mandl, H. \& Klevers, M. Psychological perspectives on motivation through gamification. Interaction Design and Architecture Journal, 2013, 19, pp. 28-37.

[34] Albrecht, S.C. The game of apiñes. Gamification of positive activity interventions, Maastricht: Maastricht University, 2012.

[35] Blanton, R. Zombies and international relations: a simple guide for bringing the undead into your classroom. International Studies Perspectives, 2012, 14 (1), pp. 1-13. https://doi.or $\mathrm{g} / 10.1111 / \mathrm{j} .1528-3585.2012 .00505 . \mathrm{x}$

[36] Ortiz-Colón, A.M., Jordán, J. \& Agredal, M. Gamificación en educación: una panorámica sobre el estado de la cuestión. Educação e Pesquisa, 2018, 44, pp. 1-17. https://dx.doi.org/ 10.1590/S1678-4634201844173773

[37] Foncubierta, J.M. \& Rodríguez, Ch. Didáctica de la gamificación en la clase de español. Editorial Edinumen, 2014. [Accessed: 20/01/2019] https://www.edinumen.es/spanish challenge/gamificacion_didactica.pdf. https://doi.org/10.18002/ehf.v0i25.4606

[38] Gallego-Durán, F.J., Villagrá-Arnedo, C.J., Satorre,R., Compañ, P., Molina-Carmona, P. \& Llorens, F Panorámica: serious games, gamification y mucho más. ReVisión, 2014, 7 (2), pp. 13-23. https://doi.org/10.3390/informatics6040049

[39] Díaz, J. \& Troyano Y. El potencial de la gamificación aplicado al ámbito educativo. En III Jornadas de Innovación Docente. Innovación Educativa: respuesta en tiempos de incertidumbre. Sevilla, España: Universidad de Sevilla. Facultad de Ciencias de la Educación, 2013. https://doi.org/10.12795/jdu.2018.i01.38

[40] Yunyongying, P. Gamification: implications for curricular desing. Journal of Graduate Medical Education, 2014, 6(3), pp. 410-412. https://doi.org/10.4300/jgme-d-13-00406.1

[41] Werbach, K. \& Hunter, D. The Gamification Toolkit: Dynamics, Mechanics, and Components for the Win. Pennsylvania: Wharton Digital Press, 2012.

[42] Argibay, J.C. Técnicas psicométricas. Cuestiones de validez y confiabilidad. Subjetividad y Procesos Cognitivos, 2006, 8, pp. 15-33.

[43] Argibay, J.C. Muestra en investigación cuantitativa. Subjetividad y Procesos Cognitivos, 2009, 13(1), pp. 13-29.

[44] Buendía, L., Colás, P. \& Hernández, F. Métodos de investigación en Psicopedagogía, Madrid, McGraw-Hill, 1998.

[45] Tashakkori, A. \& Teddlie, C.H. Quality of inferences in Mixed Methods Research: Calling for an integrative framework, In M. Bergman (Ed.), Advances in Mixed Methods Research: Theories and Applications (pp. 101-119), California: Sage Publication, 2008. https: //doi.org/10.4135/9780857024329.d10 
[46] Ato, M., López, J.J. \& Benavente, A. Un sistema de clasificación de los diseños de investigación en psicología. Anales de Psicología, 2013, 29(3), pp. 1038-1059. https://doi.org/ $\underline{10.6018 / \text { analesps.29.3.178511 }}$

[47] Pardo, A.M., Ruiz, A., \& San-Martín, R. Análisis de datos en ciencias sociales y de la salud I. Madrid: Síntesis, 2015. https://doi.org/10.7203/attic.19.10586

[48] Gómez-Trigueros, I.M. El modelo TPACK en los estudios de Grado para la formación inicial del profesorado en TIC. Didáctica Geográfica, 2015, 16, pp. 185-201.

[49] Hernández, R., Fernández, C. \& Baptista, P. Metodología de la Investigación. México: McGraw-Hill, 2003.

[50] Bisquerra, R. (Coord.). Metodología de la investigación educativa, Madrid: La Muralla, 2004.

[51] Díez, E.J. Modelos socioconstructivistas y colaborativos en el uso de las TIC en la formación inicial del profesorado. Revista de Educación, 2012, 358, pp. 175-196. https://doi. org/10.24310/innoeduca.2018.v4i2.4923.s949

[52] Roig, R., Mengual, S., Sterrantino, C. \& Quinto, P. Actitudes hacia los recursos tecnológicos en el aula de los futuros docentes. @tic. Revista d'innovació educativa, 2015, 15, pp. 12-19. https://doi.org/10.7203/attic.15.7220 https://doi.org/10.7203/attic.9.1958

[53] Valderrama, C.E. Sociedad de la información: hegemonía, reduccionismo tecnológico y resistencias. Nómadas, 2012, 36, pp. 13-25.

[54] Contreras, R. Juegos digitales y gamificación aplicados en el ámbito de la educación. RIED. Revista Iberoamericana de Educación a Distancia, 2016, 19(2), pp. 27-33. http://dx. doi.org/10.5944/ried.19.2.16143

[55] Labrador, E. \& Villegas, E. Unir gamificación y experiencia de usuario para mejorar la experiencia docente. RIED. Revista Iberoamericana de Educación a Distancia, 2016, 19(2), pp. 125-142. https://doi.org/10.5944/ried.19.2.15748

[56] Emine, S., Emre, U. \& Kamil, I. Creencias sobre alfabetización mediática en profesores y estudiantes de Educación Primaria. Comunicar, 2014, 21(42), pp. 119-127. https://doi.org/ $\underline{10.3916 / C 42-2014-11}$

[57] Cabero, J.Formación del profesorado en TIC. El gran caballo de batalla. Comunicación y Pedagogía: Revista de Nuevas Tecnologías y Recursos Didácticos, 2004, 195, pp.27-37.

[58] Cabezas, M., Casillas S. \& Pinto A.M Percepción de los alumnos de Educación Primaria de la Universidad de Salamanca sobre su competencia digital. EDUTEC, Revista Electrónica de Tecnología Educativa, 2014, 48. https://doi.org/10.21556/edutec.2019.69.1295

[59] UNESCO. Aprender a ser: la educación del futuro. París: UNESCO, 1972.

[60] UNESCO. La educación encierra un tesoro, informe a la UNESCO de la Comisión Internacional sobre la Educación para el Siglo XXI. París: UNESCO, 1996. https://doi.org/10.1 6925/greylit.2051

[61] UNESCO. Replantear la Educación ¿Hacia un bien común mundial?. París: UNESCO, 2015. https://doi.org/10.16925/greylit.2051

[62] Gómez, I.M. \& Ortega, D. Los MOOC en la Didáctica de la Geografía: Aplicaciones en la formación inicial del profesorado de Primaria. En R. Martínez y E. Tonda (Eds.), Nuevas perspectivas conceptuales y metodológicas para la educación geográfica (pp. 229-244). Córdoba: Universidad de Córdoba, 2014. https://doi.org/10.35376/10324/5691 


\section{$7 \quad$ Author}

Isabel María Gómez Trigueros is a teacher in the Department of Didactics of Social Sciences of the Faculty of Education of the University of Alicante (Spain). She leads the Educational Innovation Project of the Vice Chancellor for Innovation and Research of the University of Alicante and the Institute of Education Sciences of the University of Alicante: "Teacher training from an interdisciplinary perspective with ICT and TAC: Challenges facing the century XXI "(REDESI3CE2018-4351).

Article submitted 2019-05-03. Resubmitted 2019-06-20. Final acceptance 2019-11-02. Final version published as submitted by the authors. 